\title{
Estimation of growth and yielding of highbush blueberry (Vaccinium corymbosum L.) cultivated on soil developed from weakly loamy sand
}

\author{
Dariusz Wach
}

\author{
Department of Soil Cultivation and Fertilisation of Horticultural Plants \\ Faculty of Horticulture, University of Life Sciences \\ Akademicka 13, 20-950 Lublin, Poland \\ e-mail: dariusz.wach@up.lublin.pl
}

Key words: vegetative growth, yield, fruit size, fruit ripening

\begin{abstract}
In the years 1996 - 1999 an estimation of the growth and yielding of highbush blueberry cultivated on soil developed from weakly loamy sand was carried out. The study covered the initial years of fruit bearing (3-6 years after planting) of six cultivars of highbush blueberry: 'Bluecrop', 'Blueray', 'Darrow', 'Ivanhoe', 'Northland' and 'Spartan'. The strongest vegetative growth was characteristic for bushes of 'Northland' and 'Bluecrop' cultivars, while the weakest was found in 'Darrow' and 'Spartan'. 'Northland' proved to be the best yielding cultivar, although its fruits were the smallest. Berries of the 'Darrow' cultivar were the largest. In the study, the highest ranking was awarded to 'Bluecrop' (for growth, yielding, fruit size) and 'Northland' (for growth and yielding).
\end{abstract}




\section{INTRODUCTION}

Highbush blueberry (Vaccinium corymbosum L.) is one of the youngest orchard plants, and has highly specific requirements with respect to soil. Its cultivation is the most successful on light, humus, well aerated, acid and warm soils. Soil priming with sawdust, peat and bark, and mulching are especially recommended in blueberry cultivation on mineral soils with low humus content (Moore 1993). In the opinion of Pliszka (2002), the optimum $\mathrm{pH}_{\mathrm{KCl}}$ of soil is from 3.8 to 4.5. In recent years, in Poland as well as abroad, there has been an increase in the acreage of highbush blueberry plantings. The world leader in the cultivation of the species is the USA, with 22,440 ha. Large areas of highbush blueberry plantations can be found in China - 10,000 ha, Canada - 4,397 ha, Chile - 2,500 ha, Argentina 1,200 ha, and in Germany - over 1,000 ha (Banados 2006, Strik 2006). In Poland highbush blueberry is now grown on about 1,000 ha (Smolarz 2006).

The objective of the study was the estimation of highbush blueberry growth and yielding on production plantations under the climate and soil conditions of the Lublin region.

\section{MATERIAL AND METHODS}

In the years 1996 - 1999 a study on the growth and yielding of highbush blueberry was conducted on a plantation in Niemce near Lublin. The plantation was established in the spring of 1993, on a soil developed from weakly loamy sand. Two-year-old bushes of six highbush blueberry cultivars ('Bluecrop', 'Blueray', 'Darrow', 'Ivanhoe', 'Northland' and 'Spartan') were planted at $2 \times 1 \mathrm{~m}$ spacing. The rows of plants were mulched with a layer of sawdust $60 \mathrm{~cm}$ wide and $15 \mathrm{~cm}$ deep. The inter-rows were covered with turf. Drip irrigation was applied at the plantation. The annual dose of irrigation water was $400 \mathrm{~m}^{3} \mathrm{ha}^{-1}$. The soil had a highly acid reaction $\left(\mathrm{pH}_{\mathrm{KCl}} 3.8-4.5\right)$. Every year the plants were fertilised with ammonium sulphate at the dose of $60 \mathrm{~kg} \mathrm{~N} \mathrm{ha}^{-1}$ split in three parts, and with potassium sulphate and magnesium sulphate at doses of $60 \mathrm{~kg} \mathrm{~K}_{2} \mathrm{O}$ and $10 \mathrm{~kg} \mathrm{MgO}$ on the whole surface, respectively.

The determinations and measurements included the following:

- height of plants, number and total length of annual shoots measured in spring,

-time of ripening,

- level of commercial yield,

- weight and diameter of 100 fruits for berries from every harvest.

The study was conducted on 40 bushes in 4 replications, with 10 plants per replication. 
The results were processed statistically using analysis of variance. The significance of differences was estimated with Tukey intervals of confidence at the level of significance $\mathrm{p}=0.05$.

\section{RESULTS AND DISCUSSION}

The climatic conditions prevailing during the experiments are presented in Table 1. The average annual air temperature of the coldest year, 1996 , was $6.2^{\circ} \mathrm{C}$, and it was lower by $1.2^{\circ} \mathrm{C}$ from the long-term average. In the final - and warmest - year of the study the temperature was higher by $0.5^{\circ} \mathrm{C}$ than the long-term average. In the years 1996 and 1999 the annual sums of precipitation exceeded $600 \mathrm{~mm}$, but its distribution was varied. The highest amounts of precipitation were recorded in July 1997, June 1999 and in May 1996, when they exceeded the long-term average values by $200-250 \%$. The smallest amounts of rainfall were observed in April and June 1996, June 1997, and in August of 1997 and 1999, when they amounted to approximately $50 \%$ of the long-term standard.

According to Hancock and Draper (1989), the height of the plants of cultivated highbush blueberry cultivars usually does not exceed $250 \mathrm{~cm}$. According to Pomology, strongly growing cultivars include, among others, 'Bluecrop', 'Blueray', 'Ivanhoe' and 'Spartan' (Smolarz 2000). The growth size and strength of the bushes on the highbush blueberry plantation in the years $1996-1999$ are presented in Table 2 .

In the course of the study the height of the highbush blueberry bushes increased. The highest were the bushes of 'Bluecrop' and 'Northland' cultivars at $1.11 \mathrm{~m}$, and the lowest were those of the 'Darrow' cultivar at $0.68 \mathrm{~m}$. Under the conditions of the experiment, the strongest growth was characteristic of 'Northland' bushes, which produced the largest number of annual shoots with the highest total length (4.43 pcs bush ${ }^{-1}$ and $3.48 \mathrm{~m} \mathrm{bush}^{-1}$, respectively).

The terms of highbush blueberry ripening in the years $1996-1999$ are given in Table 3.

Highbush blueberry revealed a certain variability in the time of berry ripening within the period of the study, which was affected by the weather conditions. In the final and warmest year of the study, 1999, the highest air temperatures were recorded in June and July, which accelerated fruit ripening by as much as two weeks compared to the first and second years of the study. 

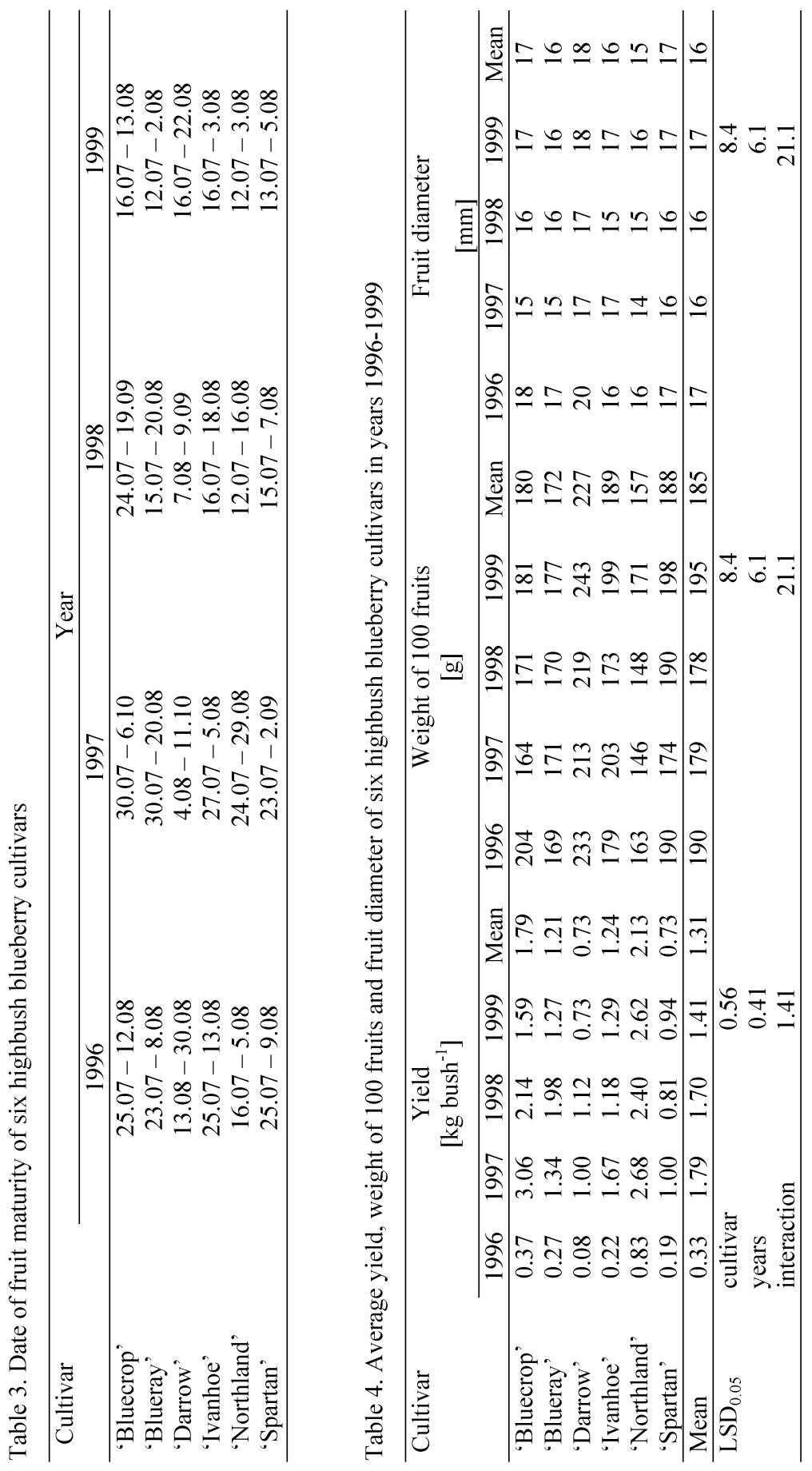
Under the conditions of the experiment, the highest total yield of berries from the $3^{\text {rd }}$ to the $6^{\text {th }}$ year after planting characterised the 'Northland' cultivar $42.64 \mathrm{t} \mathrm{ha}^{-1}$, followed by 'Bluecrop' $-35.81 \mathrm{t} \mathrm{ha}^{-1}$ (Fig. 1). Koziński (2006), in his studies on fertilisation and mulching of 'Bluecrop' highbush blueberry, obtained for plants of similar age - a three year total yield above $90 \mathrm{t} \mathrm{ha}^{-1}$ on soil mulched with sawdust and on soil mixed and mulched with sawdust at a nitrogen fertilisation rate of $60 \mathrm{~kg} \mathrm{ha}^{-1}$.

Under the climate and soil conditions of Poland, highbush blueberry grows and yields well, but the results reflecting its yielding are fairly varied (Chlebowska and Smolarz 1997, Smolarz 1997). In central Poland very good yields have been obtained - almost $10 \mathrm{~kg}$ per bush (Smolarz 2005). Young plants that enter the period of fructification produce low yields but are characterised by increasing productivity, reaching full fructification in the $6^{\text {th }}-8^{\text {th }}$ year after planting (Eynard et al. 1985). The study presented herein represents the period of entry into fructification of six highbush blueberry cultivars (Table 4).

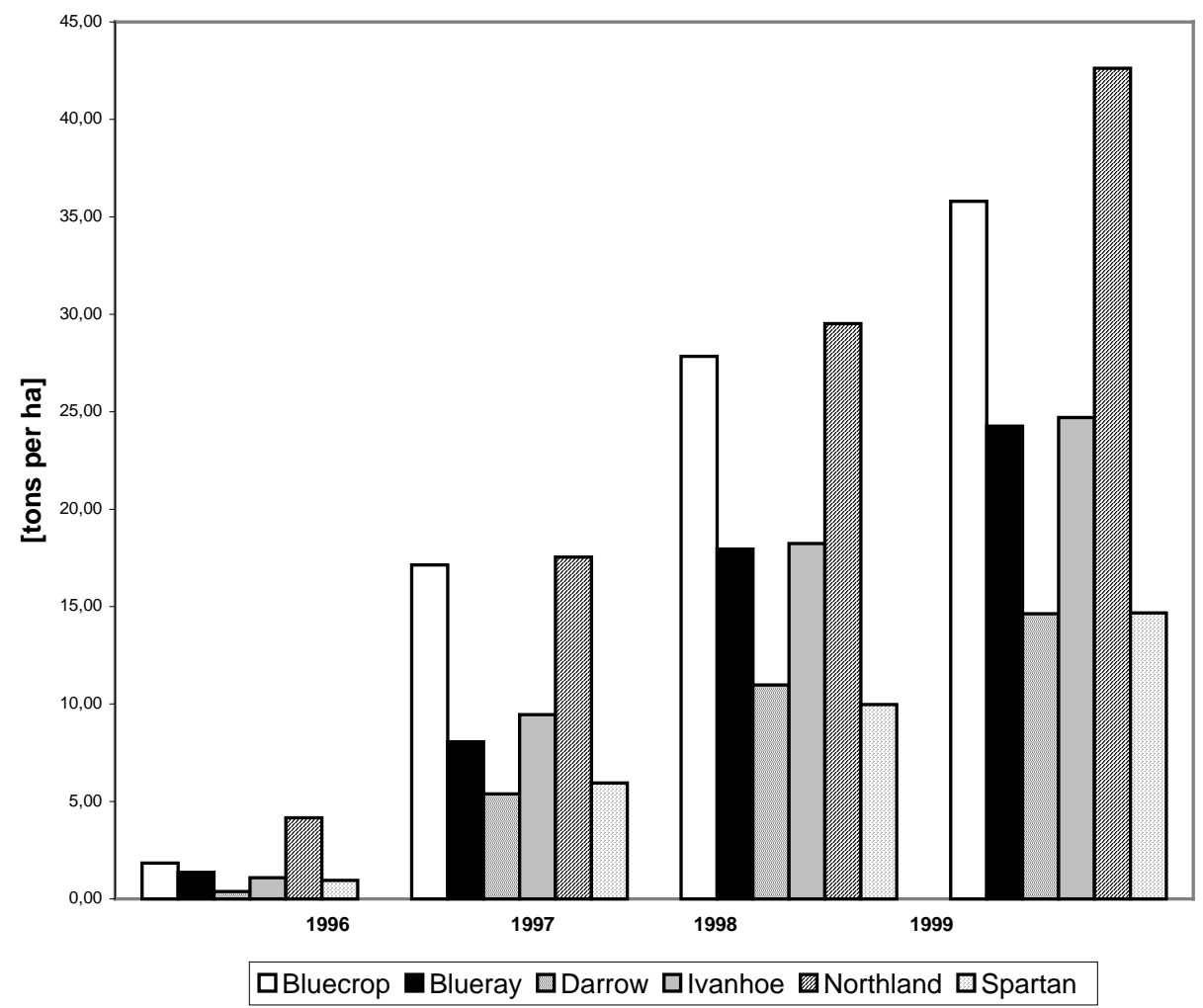

Fig. 1. Cumulative yield of six highbush blueberry cultivars in the years $1996-1999$ 
Under the conditions of the experiment the yields of highbush blueberry varied from $0.33 \mathrm{~kg} \mathrm{bush}{ }^{-1}$ in 1996 to $1.79 \mathrm{~kg} \mathrm{bush}^{-1}$ in 1997. In an estimation excluding the years of the study, the highest yield was produced by 'Northland' $(2.13 \mathrm{~kg}$ bush $\left.^{-1}\right)$, and the lowest by 'Darrow' and 'Spartan' $\left(0.73 \mathrm{~kg} \mathrm{bush}^{-1}\right)$. The yielding of cultivars 'Bluecrop', 'Blueray', 'Northland' and 'Darrow' on the plantation in Niemce was higher, and that of 'Spartan' lower than those obtained in American studies (Nelson 1985). In certain experiments abroad, yields lower than those in Niemce were obtained for 'Northland' berries (Lareau 1985, Kaps and Odneal 1998), while in Norway the cultivar 'Northland' yielded at levels comparable to those obtained in the study presented herein (Øydvin and Øydvin 1999). Under Polish conditions yields of highbush blueberry have been obtained at levels that were both lower (Kawecki and Kopytowski 1991, Chlebowska and Smolarz 1997) and higher (Kropp et al. 1992) than in the study presented here.

High yields entail a reduction in the weight and size of a single fruit, which was demonstrated, with the example of nine highbush blueberry cultivars, by Siefker and Hancock (1986), and which was also observed in this experiment. The study showed that the largest berries were characteristic of 'Darrow', which is in agreement with all literature data (Eynard et al. 1985, Smolarz 1997, Małodobry et al. 2001). A decreasing order of hierarchy of cultivars favourable in terms of that feature included 'Bluecrop', 'Spartan', 'Ivanhoe' and 'Blueray'. The smallest fruits in the experiment were produced by 'Northland', which is also in agreement with the results of studies by other authors (Austin and Bondari 1989, Kaps and Odneal 1998).

\section{CONCLUSIONS}

1. Bushes of 'Northland' and 'Bluecrop' cultivars attained the largest sizes and were characterised by the strongest vegetative growth, while the growth of 'Darrow' and 'Spartan' cultivars was the weakest.

2. The fruits of 'Northland' started to ripen the earliest. Air temperatures in the summer months of 1999, higher than the long-term average, accelerated the ripening of berries of all the cultivars compared to the first and second years of the study.

3. 'Northland' proved to be the highest yielding, but it produced the smallest fruits. 'Bluecrop' also produced good yields, while the lowest yielding were 'Darrow' and 'Spartan' cultivars.

4. The highest values of fruit weight and diameter were characteristic of the berries of 'Darrow'. Also good in that respect were 'Spartan', 'Ivanhoe' and 'Bluecrop' cultivars.

5. In the study, the best overall were 'Bluecrop' (growth, yielding, berry size) and 'Northland' (growth, yielding) cultivars. 


\section{REFERENCES}

Austin M.E., BONDARI K., 1989. Production of highbush blueberry cultivars in the mountains of Georgia. Acta Hort. 241: 71-76.

BANADOS M.P., 2006. Blueberry production in South America. Acta Hort. 715: $165-172$.

ChlebowsKa D., Smolarz K., 1997. Wzrost i plonowanie kilku odmian borówki wysokiej (Vaccinium corymbosum L.). Zesz. Nauk. Inst. Sadow. Kwiac. 4: 75-84.

EYNARD I., GAY G., SAVINO P.G., 1985. Highbush blueberry cultivar testing in Italy. A twenty years experiment. Acta Hort. 165: 53-60.

HANCOCK J., DRAPER A.D., 1989. Blueberry culture in North America. Hort. Sci. 24: 551-556.

KAPS M.L., ODNEAL M.B., 1998. Blueberry cultivar evaluation on a high pH site in Missouri. Fruit Var. J. 52(2): 91-95.

KAWECKI Z., KOPYTOWSKI J., 1991. Wzrost i plonowanie krzewów borówki wysokiej nawożonych mieszanką nawozową Mis-3. I. Morfologia i plonowanie krzewów. Acta Acad. Agricult. Tech. Olst., Agricult. 52: 175-184.

KOZIŃSKI B., 2006. Influence of mulching and nitrogen fertilization rate on growth and yield of highbush blueberry. Acta Hort. 715: 231-236.

KropP K., MAŁODOBRY M., KlAMCZYŃSKI A., 1992. Wzrost i plonowanie 4 odmian borówki wysokiej w rejonie podkrakowskim. Prace Inst. Sadow. Kwiac. Seria C(3-4): 249-250.

LAREAU M.J., 1985. Cultivar and soil management studies of highbush blueberries in Quebec. Acta Hort. 165: 115-121.

MAŁODOBRY M., LECH W., DZIEDZIC E., KOWALSKI J., 2001. Estimation of growth and yielding of four highbush blueberry cultivars. Folia Hort. 13(1): 73-82.

MOORE J.N., 1993. Adapting low organic upland mineral soils for culture of highbush blueberries. Acta Hort. 346: 221-229.

NELSON J.W., 1985. Results of a twenty year blueberry cultivar trial at Grand Junction, Michigan, USA. Acta Hort. 165: 21-27.

ØYDVIN J., ØYDVIN B., 1999. Highbush blueberry crops in a trial in Norway, 1988 - 1998. Fruit Var. J. 53(3): 155-159.

PLISZKA K., 2002. Borówka wysoka. PWRiL, Warszawa: 28.

SIEFKER J.A., HANCOCK J.F., 1986. Yield component interactions in cultivars of the highbush blueberry. J. Amer. Soc. Hort. Sci. 111(4): 606-608.

SMOLARZ K., 1997. Wzrost i plonowanie 12 odmian borówki wysokiej w środkowej części Polski. Zesz. Nauk. Inst. Sadow. Kwiac. 4: 97-109.

Smolarz K., 2000. Borówka wysoka. Zesz. Pom. Inst. Sadow. Kwiac., Skierniewice. 
SMOLARZ K., 2005. Wpływ cięcia odmładzającego i nawożenia azotem na plonowanie borówki wysokiej odmiany „Bluecrop”. Zesz. Nauk. Inst. Sadow. Kwiac. 13: 83-91.

SMOLARZ K., 2006. History of highbush bluerry (V. corymbosum L.) growing in Poland. Acta Hort. 715: 313-315.

STRIK B., 2006. Blueberry production and research trends in North America. Acta Hort. 715: 173-183.

OCENA WZROSTU I PLONOWANIA BORÓWKI WYSOKIEJ (VACCINIUM CORYMBOSUM L.) UPRAWIANEJ NA GLEBIE WYTWORZONEJ Z PIASKU SŁABOGLINIASTEGO

Streszczenie: W latach 1996-1999 przeprowadzono ocenę wzrostu i plonowania borówki wysokiej uprawianej na glebie wytworzonej $\mathrm{z}$ piasku słabogliniastego. Badania obejmowały pierwsze lata owocowania (3-6 rok po posadzeniu) sześciu odmian borówki wysokiej: 'Bluecrop', 'Blueray', 'Darrow', 'Ivanhoe', 'Northland' i 'Spartan'. Najsilniejszym wzrostem wegetatywnym charakteryzowały się krzewy odmian 'Northland' i 'Bluecrop', zaś najsłabszym 'Darrow' i 'Spartan'. Najplen-niejsza okazała się odmiana 'Northland' chociaż jej owoce były najmniejsze. Jagody odmiany 'Darrow' były największe. W badaniach najkorzystniej oceniono odmianę 'Bluecrop' (wzrost, plonowanie, wielkość owoców) i 'Northland' (wzrost, plonowanie). 